\title{
The Interface between Iranian EFL Instructors' Personality and their Self-efficacy
}

\author{
Ali Rahimi (corresponding author) \\ Bangkok University, THAILAND \\ E-mail: rahimi_cda@yahoo.com \\ Maryam Saberi \\ Department of English Language Teaching, Science and Research branch, Islamic Azad University, Bandar Abbass, Iran \\ Doi:10.7575/aiac.alls.v.5n.3p.134 \\ Received: 01/04/2014 \\ URL: http://dx.doi.org/10.7575/aiac.alls.v.5n.3p.134 \\ Accepted: 15/05/2014
}

\begin{abstract}
In recent years, teachers' self-efficacy has demonstrated a profound influence on the daily lives of teachers and their students. However, little is known about the relationship between teachers' personality traits and their self-efficacy. To gain more insight into this area, this study sought to explore the interface between 100 male and female EFL instructors' personality and their self-efficacy at 11 English language institutes in Bandar Abbas, Iran. In order to glean data, two instruments were applied: the NEO Five Factor Inventory (NEO-FFIR), and Second Language Teaching Efficacy Scale (SLTES). Moreover, to see whether there was a significant relationship between the variables under study, Spearman Rank Order

Correlation was applied to analyze the data. At the end, the results revealed a significant relationship between EFL instructors' personality and their self-efficacy. In addition, it is concluded that there is a meaningful and positive relationship between Extroversion, Openness, Agreeableness, Conscientiousness, and the traits of self-efficacy; nevertheless, the relationship between Neuroticism and each trait of self-efficacy turns out to be negative. Moreover, the results revealed that Agreeableness is the best predictor for student engagement, extraversion is the most important predictor for instructional strategies and classroom management, and the best predictors of self-efficacy are classroom management for extraversion and student engagement for agreeableness.
\end{abstract}

Keywords: self-efficacy, teachers' efficacy, personality, personality traits

\section{Introduction}

The late nineteenth century was the first time that the word personality came about. Smith (1997) stated that the use of personality assessments was referred to as "psychotechnics" and it was during this time that personality assessments became a growing trend. Assessments were used to determine a person's complex elation to life (Smith, 1997).

As Homer explained (1997) the first salient and socially relevant personality assessment to be recognized was that the Lexical Hypothesis developed by Galton. By working through woof the most ample dictionaries of the English language Allport and Odbert (1936) expanded Galton's hypothesis. They extracted eighteen thousand Personalitydescribing words. In 1937 Allport and Odbert reduced the list to a list which consisted of four thousand five hundred adjectives. These adjectives were well thought-out, observable and moderately permanent qualities (Homer, 1997).

For the next two decades, personality research proved difficult. In the 1980s methodologies were questioned. Homer's idea (1997) was challenged by proposing that instead of attempting to predict solitary in stances of behavior, a method which was not dependable, methodologies might calculate patterns of behavior by culminating large numbers of observations. The correlation linking personality and behavior was found to improve significantly, and "personality" obviously did really exist. Then, psychologists agreed with the intention of fully explaining individual behavior, that personality and situational variables were desired. Trait theories were then acceptable, and there was a renewed awareness in this area. Goldberg (1981) once again found the Five Factor Model when he began his own venture with a newest of words.

Barrick and Mount (1991) studied and revised the five factors to: Extraversion, Agreeableness, Conscientiousness, Neuroticism, and Openness to Experience. According to John, et al., (1991), the factors were simulated by Norman (1963), who defined the five factors. However, Tellegen (1985), McCrae and Costa (1990), and John (1990), briefly described the five factors as: (I) Extraversion, an energetic move towards the societal and materialistic world (hospitality, doings, self-assurance, and positive emotionality); (II) Agreeableness, which contrasts a pro-communal and shared orientation towards others with opposition (altruism, modesty, tender-mindedness, trustfulness); (III) Conscientiousness, which describes communally-prescribed controlling whims that direct task and goal-specific behavior such as thinking before responding, prolonging gratification, and attending to the norm and rules, (planner, organized, prioritizing); (IV) Neuroticism, which contrasts emotional stability and level temperedness with 
unconstructive emotions (apprehensive, edgy, distressing, uptight); and finally, (V) Openness to experience describes the depth, uniqueness, and intricacy or emotional stability based on an individual's psychological and pragmatic life (calm, not neurotic, not easily upset) (p.138). A separate power of the Big Five classification was that it could summarize a broad level of concepts, and common alities amid the existing personality styles (Pinker, 1997). Consequently, the Big Five Instrument provides a detailed descriptive model for research.

Across professions, personality characteristics are shown to affect job performance (Barrick \& Mount, 1991; Lounbury, Park, Sundstorm, Williamson, \& Pemberton, 2004; Rothstein \& Goffin, 2006; Ones, Dilchert, Viswesraran, \& Judge, 2007), and teaching does not seem to be an exception. Personality is related to teachers' teaching style (Zhang, 2007), job satisfaction (Jacquez, 2004), burnout (Cano-Garsia, Padilla-Munoz, \& Carrasca-Oritz, 2005), teaching quality (Emmerich, Roch, \& Trapani, 2006) as well as teacher performance and student achievement (Bowers, 2006).

Self-efficacy is defined as "people's judgments of their capabilities to organize and execute courses of action required attaining designated types of performances." (Bandura, 1986, p.391). A group of researchers expanded the definition of self-efficacy by adding that self-efficacy "refers to beliefs in one's capabilities to mobilize the motivation, cognitive resources, and courses of action needed to meet situational demands." (Wood \& Bandura, 1989, p.408) Mitchell, et al., (1994, p.506) concluded that self-efficacy "refers to what a person believe he or she can do on a particular task."

Because efficacy expectations serve as a behavioral predictor, they have been impact levels of performance in a number of ways (Bandura, 1986). They affect aspects such as goal setting, choice of activity, amount of effort that will expended, analytic strategies and persistence of coping behavior. (Bandura, 1977; Wood \& Bandura, 1989)

This study dealt with EFL instructors' personality and their self-efficacy. In order to understand their interface, this study discussed these two components and made an attempt to explore the relationship between them. These two components are EFL teachers' personality and their self-efficacy.

\section{Statement of the problem}

In this study, teaching effectiveness is measured through personality. As mentioned by Fisler and Firestone (2004), teacher performance is influenced by the teachers' personality characteristics and their efficacy belief in teaching. Based on the previous study by Azlina and Tan (2003), in general, most of the teacher's personality is agreeableness and the less is neuroticism. However, the problems may arise on how to identify the personality dimension of teacher based on the model of McCrae \& Costa (1997), "The Big Five: Neuroticism, Extraversion, Openness, Agreeableness and Conscientiousness". As stated by Schmidt et. Al (1991), that there are numerous studies showing that personality is a significant predictor of effective teaching. Understanding personality types might help teachers to implement their performance easily. Further, the relationship between these personality types and teaching effectiveness and how the first one influences the latter is one of the great concerns of this study. This study is an attempt to fill the gap in this area and provide more profound insights into the parameters involved as the contribution to this discipline.

\section{Significance of the study}

Findings of this study would greatly benefit secondary schools and teachers. Schools can have a clear view on what is the best approach to be practiced in order to support that plan. Talbert and McClaughlin (1994) mentioned that teacher's work occurs within a community supported by administrators and peers who provide tools and support for effective work. Since there are commitments from schools, teachers can improve the quality of their work.

Teachers may know themselves and how to integrate their personality strength to make their teaching techniques effective, a necessary condition in achieving their desired goals. Every teacher has his/her own specific teaching style. According to Rubin (1985), teaching styles involve choices and alternatives and the choices teachers make actually demonstrate their perceived images and roles. Through their style, teachers integrate the theories or pedagogy in which they believe and the practices they adopt in the classroom. Therefore, the compatibility between teaching styles and personality types will lead to the effectiveness of teaching techniques and procedures. On the whole, the results of this study can create the necessary awareness among language teachers regarding how their personality traits are correlated with their self-efficacy and the like.

\subsection{Objective of the study}

The purpose of this study was to determine if any relationships exists between teaching efficacy and personality types of EFL teachers in the context of language education in Iran. Therefore, this objective was sought in this study:

- Examining relationships between teaching efficacy and personality type of Iranian EFL teachers.

\subsection{Research questions and hypothesis:}

To achieve the objectives of this study, the following questions were raised:

1. Is there any significant relationship between each personality trait and each component of teacher selfefficacy?

2. Which personality trait accounts for teacher efficacy beliefs most considerably?

3. Which teacher efficacy component accounts for which personality trait most considerably?

Based on the above questions, the following null hypothesis was made:

1. There is no significant relationship between each personality traits and each component of teacher selfefficacy. 


\section{Participants}

Participants in this study were 100 male and female teachers (23 males and 77 females) ranging in age from 25 to 40 , holding B.A and M.A in TEFL and teaching EFL courses at Morvarid Jonub, Tehran Language Institute, Safir, Parsa, Mehrdad, Latidan, Dana, Aryan, Farhikhtegan, Arman and Kish language institutes in Bandar Abbas, Iran (Persia). These institutes were selected because they were among the most creditable private language institutes.

\section{Instrumentation}

In order to glean the data, two instruments were utilized: The NEO-Five Factor Inventory (NEO-FFL) and second language teaching efficacy scale (SLTES).

\subsection{NEO-Five Factor Inventory (NEO-FFL)}

The Persian adaptation of Neo Five Factor inventory (Costa and McCrae, 1999) was used to measure personality. The Neo FFI is a self-report paper and pencil questionnaire which covers the five main domains of the Big Five Model. The five dimensions of personality which were measured are: neuroticism, extraversion, openness, agreeableness, and conscientiousness. The inventory consists of 240 items that are scored according to Likert type scale of five points ranging from strongly disagree to strongly agree. It should be noted that Garousi, Mehrya, and Ghazi Tabatabae (2001) examined the reliability and validity of this inventory and approved it for application in Iran. They estimated the reliability of this instrument to be between 0.77 and 0.92 .After administration phase and the data collection process, the researchers employed Cronbach's Alpha. The results revealed the reliability of 0.93 .

\subsection{Second Language Teaching Efficacy Scale}

To assess teacher self-efficacy and of the various instruments available for assessing teacher self-efficacy, the second language teaching efficacy scale (SLTES), which is developed by Akbari and Abednia (2009) was used. This instrument assesses teachers' self-efficacy in three areas: 1. Instructional strategies, 2. Classroom management 3.student engagement. The construct of efficacy was scored based on Likert-scale of five points ranging from a great deal to nothing. By using Cronbach alpha, they found out that the reliability of the instrument was 0.93 and also the estimated reliability for different factors was 0.89 for instructional strategies, 0.85 for classroom management, and 0.83 for student engagement. Moreover, the researchers estimated the reliability of this instrument as 0.95 by the use of Cronbach alpha.

\section{Design of the study}

The present study has the characteristics of a descriptive study. Based upon the features of this kind of research, the researchers tested the hypothesis and found out the relationship between variables, so it is a correlational, quantitative study which could be generalizable to larger settings. (Best \& Kahn, 2006).

\subsection{Data Collection Procedure}

The administration stage was done in one session. The teachers were asked to fill out the NEO-Five Factor Inventory and Second Language Teaching Efficacy Scale questionnaires. The 100 participants of the study, the teachers at the language institutes, holding B.A and M.A degrees rated themselves on 5 point Likert- scale of Neo, from strongly disagree to strongly agree and on 9 point Likert- scale of SLTES from 1 to 9. The data collection process took two months, then the answers to the questionnaires were analyzed by the application of the SPSS software.

\subsection{Data analysis Procedure}

The data which were gathered from the two questionnaires were analyzed by utilizing Spearman rank order to determine the correlation between the two main variables. Multiple regression analysis was also used for measuring and determining which combination of independent variables best predicts or explains the variation in one dependent variable.

The descriptive statistics for the NEO-FFL variables are shown in the table 1 . The means in the five personality dimension show that teachers rated themselves highest in Conscientiousness (2.17), then Extraversion (2.14), openness (2.12), agreeableness (2.10) and neuroticism (1.96)

Table 1. Report

\begin{tabular}{llllll}
\hline & Neuroticism & Extraversion & Openness & Agreeableness & Conscientiousness \\
\hline Mean & 1.96 & 2.14 & 2.12 & 2.10 & 2.17 \\
$\mathrm{~N}$ & 100 & 100 & 100 & 100 & 100 \\
\hline
\end{tabular}

The descriptive statistics for the self-report efficacy are shown in the table 2 . The means in the three subscales indicate that participants judged themselves to be more efficacious for classroom management (6.62) than for student engagement (6.52) and instructional strategies (6.54) .In other words, they perceived themselves more efficacious and capable in managing the classroom than designing instructional strategies and engaging students in the classroom activities. 
Table 2. Report

\begin{tabular}{llll}
\hline & $\begin{array}{l}\text { Student } \\
\text { Engagement }\end{array}$ & $\begin{array}{l}\text { Instructional } \\
\text { Strategies }\end{array}$ & $\begin{array}{l}\text { Classroom } \\
\text { Management }\end{array}$ \\
\hline Mean & 6.52 & 6.54 & 6.62 \\
Std. Deviation & 17.82400 & 17.61925 & 14.22890 \\
Minimum & 20.00 & 24.00 & 22.00 \\
Maximum & 99.00 & 108.00 & 90.00 \\
Sum & 6839.00 & 7508.00 & 6327.00 \\
$\%$ of Total N & $100.0 \%$ & $100.0 \%$ & $100.0 \%$ \\
\hline
\end{tabular}

\section{Is there any significant relationship between each personality trait and each component of teacher self-efficacy?}

In order to answer research question two, the EFL teachers' personality and their self-efficacy were scored to determine if correlation existed between these variables. Spearman rank order formula was used to calculate this correlation. Table 4 indicates the correlation between neuroticism and self-efficacy.

Table 3. Correlations between neuroticism and self-efficacy

\begin{tabular}{|c|c|c|c|c|c|c|}
\hline & & & Neuroticism & $\begin{array}{l}\text { Student } \\
\text { Engagement }\end{array}$ & $\begin{array}{l}\text { Instructional } \\
\text { Strategies }\end{array}$ & $\begin{array}{l}\text { Classroom } \\
\text { Management }\end{array}$ \\
\hline \multirow{3}{*}{$\begin{array}{l}\text { Spearman's } \\
\text { rho }\end{array}$} & \multirow{3}{*}{ Neuroticism } & $\begin{array}{l}\text { Correlation } \\
\text { Coefficient }\end{array}$ & 1.000 & -.004 & -.044 & -.046 \\
\hline & & Sig. (1-tailed) & . & .486 & .330 & .323 \\
\hline & & $\mathrm{N}$ & 100 & 100 & 100 & 100 \\
\hline
\end{tabular}

**. Correlation is significant at the 0.01 level (1-tailed).

As the table 3 has presented there is a negative relationship between neuroticism and student engagement $(\mathrm{r}=-.004$, p.486<0.05). It means that the higher the neuroticism, the lower the level of student engagement. The relationship between neuroticism and instructional strategies and classroom management are also negative, it is $(\mathrm{r}-.044, \mathrm{p} .330<0.05)$ for instructional strategies and $(r=-.046, p .323<0.05)$ for classroom management. It means that the higher the neuroticism, the lower the instructional strategies and also the higher the neuroticism, the lower the classroom management. Table 5 indicates the correlation between extraversion and self-efficacy.

Table 4. Correlations between extraversion and self-efficacy

\begin{tabular}{|c|c|c|c|c|c|c|}
\hline & & & Extraversion & $\begin{array}{l}\text { Student } \\
\text { Engagement }\end{array}$ & $\begin{array}{l}\text { Instructional } \\
\text { Strategies }\end{array}$ & $\begin{array}{l}\text { Classroom } \\
\text { Management }\end{array}$ \\
\hline \multirow{3}{*}{$\begin{array}{l}\text { Spearman's } \\
\text { rho }\end{array}$} & \multirow{3}{*}{ Extraversion } & $\begin{array}{l}\text { Correlation } \\
\text { Coefficient }\end{array}$ & 1.000 & $.260^{* *}$ & $.296^{* *}$ & $.285^{* *}$ \\
\hline & & Sig. (1-tailed) & & .004 & .001 & .002 \\
\hline & & $\mathrm{N}$ & 100 & 100 & 100 & 100 \\
\hline
\end{tabular}

**. Correlation is significant at the 0.01 level (1-tailed).

As table 4 shows there is a positive relationship between extraversion and student engagement $(r=.260, p .004<0.05)$. It means that the higher the extraversion score, the higher the level of student engagement. Furthermore, the relationship between extraversion and instructional strategies is positive $(r=.296, p=.001<0.05)$, that is, the higher the extraversion score, the higher the instructional strategies. There is a positive relationship between extraversion and classroom management $(\mathrm{r}=.285, \mathrm{p}=.002<0.05)$, in other words, the higher the extraversion score, the higher the classroom management. 
Table 5 indicates the correlation between openness and self-efficacy.

Table 5. Correlations between openness and self-efficacy

\begin{tabular}{|c|c|c|c|c|c|c|}
\hline & & & Openness & $\begin{array}{l}\text { Student } \\
\text { Engagement }\end{array}$ & $\begin{array}{l}\text { Instructional } \\
\text { Strategies }\end{array}$ & $\begin{array}{l}\text { Classroom } \\
\text { Management }\end{array}$ \\
\hline \multirow{3}{*}{$\begin{array}{l}\text { Spearman's } \\
\text { rho }\end{array}$} & \multirow{3}{*}{ Openness } & $\begin{array}{l}\text { Correlation } \\
\text { Coefficient }\end{array}$ & 1.000 & $.215^{*}$ & $.232^{*}$ & $.216^{*}$ \\
\hline & & Sig. (1-tailed) & . & .016 & .010 & .015 \\
\hline & & $\mathrm{N}$ & 100 & 100 & 100 & 100 \\
\hline
\end{tabular}

As table 5 has presented, there is a meaningful relationship between openness and student engagement $(r=.215, p=$ $0.016<0.05)$. It means that the higher the openness score, the higher the student engagement. There is also a positive relationship between openness and instructional strategies $(r=.232, p=0.010<0.05)$. It means that the higher the openness score, the higher the instructional strategies. Moreover, the relationship between openness and classroom management is positive $(\mathrm{r}=.216, \mathrm{p}=0.015<0.05)$, that is, classroom management increases with openness.

Table 7 indicates the correlation between agreeableness and self-efficacy

Table 6. Correlations between agreeableness and self-efficacy

\begin{tabular}{|c|c|c|c|c|c|c|}
\hline & & & Agreeableness & $\begin{array}{l}\text { Student } \\
\text { Engagement }\end{array}$ & $\begin{array}{l}\text { Instructional } \\
\text { Strategies }\end{array}$ & $\begin{array}{l}\text { Classroom } \\
\text { Management }\end{array}$ \\
\hline \multirow{3}{*}{$\begin{array}{l}\text { Spearman's } \\
\text { rho }\end{array}$} & \multirow{3}{*}{ Agreeableness } & $\begin{array}{l}\text { Correlation } \\
\text { Coefficient }\end{array}$ & 1.000 & $.262^{* *}$ & $.235^{* *}$ & $.227^{*}$ \\
\hline & & $\begin{array}{l}\text { Sig. (1- } \\
\text { tailed) }\end{array}$ & . & .004 & .009 & .012 \\
\hline & & $\mathrm{N}$ & 100 & 100 & 100 & 100 \\
\hline
\end{tabular}

As table 6 has illustrated, there is a positive relationship between agreeableness and student engagement $(\mathrm{r}=.262$, p.004<0.05). It means that the higher the agreeableness score, the higher the student engagement. There is a positive relationship between agreeableness and instructional strategies $(\mathrm{r}=.235, \mathrm{p} .009<0.05)$. It means that the higher the agreeableness, the higher the instructional strategies, and the relationship between agreeableness and classroom management is positive $(\mathrm{r}=.227, \mathrm{p}=.012<0.05)$, which is indicative of the increase in classroom management with higher agreeableness.

Table 7 shows the correlation between conscientiousness and self-efficacy

Table 7. Correlations between conscientiousness and self-efficacy

\begin{tabular}{|c|c|c|c|c|c|c|}
\hline & & & Conscientiousness & $\begin{array}{l}\text { Student } \\
\text { Engagement }\end{array}$ & $\begin{array}{l}\text { Instructional } \\
\text { Strategies }\end{array}$ & $\begin{array}{l}\text { Classroom } \\
\text { Management }\end{array}$ \\
\hline \multirow{3}{*}{$\begin{array}{l}\text { Spearman's } \\
\text { rho }\end{array}$} & \multirow{3}{*}{ Conscientiousness } & $\begin{array}{l}\text { Correlation } \\
\text { Coefficient }\end{array}$ & 1.000 & $.192^{*}$ & $.210^{*}$ & $.176^{*}$ \\
\hline & & Sig. (1-tailed) & . & .028 & .018 & .040 \\
\hline & & $\mathrm{N}$ & 100 & 100 & 100 & 100 \\
\hline
\end{tabular}

\footnotetext{
*. Correlation is significant at the 0.05 level (1-tailed).

**. Correlation is significant at the 0.01 level (1-tailed).
} 
As the table has presented, there is a positive relationship between conscientiousness and student engagement $(\mathrm{r}=.192$, $\mathrm{p}=.028<0.05$ ). It means that the higher the conscientiousness score, the higher the student engagement. There is also a positive relationship between conscientiousness and instructional strategies $(\mathrm{r}=.210, \mathrm{p}=.018<0.05)$, it means that the higher the conscientiousness the higher the instructional strategies, and the relationship between conscientiousness and classroom management is positive $(\mathrm{r}=.176, \mathrm{p}=.040<0.05)$, it means that the higher the conscientiousness score the higher the classroom management.

Based upon the above tables, we conclude that there is a noticeable relation between personality traits and each component of self-efficacy, this relationship is negative for neuroticism, and positive for the other personality traits (Extraversion, openness, agreeableness, and conscientiousness). Hence, these results led to the rejection of the null hypothesis.

\section{Which personality trait accounts for teacher efficacy beliefs most considerably?}

In order to find the answer to this question, multiple regression analyses were used to examine if teachers' personality based on five factor model and as measured by NEO-FFI could significantly predict their efficacy as measured by teacher efficacy scale. The scores on NEO-FFI (neuroticism, conscientiousness, extraversion, openness, agreeableness) were taken as a predictor variables and scores on teacher efficacy scale were considered as the predicted or criterion variable.

Table 8. Personality trait accounts and teacher efficacy

\begin{tabular}{|c|c|c|c|c|c|c|c|}
\hline Model & $\mathrm{R}$ & R Square & $\begin{array}{l}\text { Adjusted R } \\
\text { Square }\end{array}$ & $\begin{array}{l}\text { Std. Error of the } \\
\text { Estimate }\end{array}$ & & & \\
\hline & & & & & $\begin{array}{l}\text { R Square } \\
\text { Change }\end{array}$ & $\begin{array}{l}\text { F } \\
\text { Change }\end{array}$ & df1 \\
\hline 1 & $.251^{\mathrm{a}}$ & .063 & .053 & 17.34204 & .063 & 6.579 & 1 \\
\hline
\end{tabular}

a. Predictors: (Constant), Agreeableness

b. Dependent Variable: Student Engagement

The results shown in table 8 reveal that the model containing the total scores of agreeableness can predict 63 percent of the student engagement. The $\mathrm{R}$ value is 0.25 , which indicates the correlation coefficient between teachers' personality and their self-efficacy. The square is 0.63 , and this indicates that among the subscales of personality, agreeableness accounts for $63 \%$ of total variance in self-efficacy by itself.

Table 9. Personality trait and instructional strategies

\begin{tabular}{|c|c|c|c|c|c|c|c|}
\hline Model & $\mathrm{R}$ & R Square & $\begin{array}{l}\text { Adjusted R } \\
\text { Square }\end{array}$ & $\begin{array}{l}\text { Std. Error of the } \\
\text { Estimate }\end{array}$ & & & \\
\hline & & & & & $\begin{array}{l}\text { R Square } \\
\text { Change }\end{array}$ & $\begin{array}{l}\text { F } \\
\text { Change }\end{array}$ & df1 \\
\hline 1 & $.270^{\mathrm{a}}$ & .073 & .064 & 17.05006 & .073 & 7.720 & 1 \\
\hline
\end{tabular}

a. Predictors: (Constant), Extraversion

b. Dependent Variable: Instructional Strategies

The results presented in table 9 revealed that the model containing the total scores of the personality can predict 73 percent of the instructional strategies. The $\mathrm{R}$ value is 0.27 which indicates the correlation coefficient between teachers' personality and their self-efficacy. The square is 0.73 , and this indicates that among the subscales of personality, extraversion accounts for $73 \%$ of total variance in instructional strategies by itself. This correlation is significant at the 0.05 level. Having high extraversion score was a good predictor of instructional strategies.

\section{Which teacher efficacy component accounts for which personality trait most considerably?}

In order to find the answer to this question, multiple regression analyses were used to examine if teachers' efficacy as measured by teacher efficacy scale could significantly predict their personality based on five factor model and as measured by NEO-FFI. The scores on NEO-FFI (neuroticism, conscientiousness, extraversion, openness, and agreeableness) were taken as predicted or criterion variables and scores on teacher efficacy scale were considered as the predictor. 
Table 10. Teacher efficacy accounts and personality traits

\begin{tabular}{|c|c|c|c|c|c|c|c|}
\hline Model & $\mathrm{R}$ & R Square & $\begin{array}{l}\text { Adjusted R } \\
\text { Square }\end{array}$ & $\begin{array}{l}\text { Std. Error of the } \\
\text { Estimate }\end{array}$ & & & \\
\hline & & & & & $\begin{array}{l}\text { R Square } \\
\text { Change }\end{array}$ & F Change & df1 \\
\hline 1 & $.276^{\mathrm{a}}$ & .076 & .067 & 23.88974 & .076 & 8.112 & 1 \\
\hline
\end{tabular}

The results presented in table 10 revealed that the model containing the total scores of the classroom management can predict 76 percent of the extraversion. The $\mathrm{R}$ value is 0.27 which indicates the correlation coefficient between teachers' self-efficacy and their personality. The square is 0.76 , and this indicates that among the subscales of self-efficacy, classroom management accounts for $76 \%$ of total variance in extraversion by itself. This correlation is significant at the 0.05 level. High classroom management skills were good predictor of extraversion.

Table 11. Students' engagement and agreeableness

\begin{tabular}{|c|c|c|c|c|c|c|c|}
\hline Model & $\mathrm{R}$ & R Square & $\begin{array}{l}\text { Adjusted R } \\
\text { Square }\end{array}$ & $\begin{array}{l}\text { Std. Error of the } \\
\text { Estimate }\end{array}$ & & & \\
\hline & & & & & $\begin{array}{l}\text { R Square } \\
\text { Change }\end{array}$ & $\begin{array}{l}\mathrm{F} \\
\text { Change }\end{array}$ & df1 \\
\hline 1 & $.251^{\mathrm{a}}$ & .063 & .053 & 18.11109 & .063 & 6.579 & 1 \\
\hline
\end{tabular}

The results of table 11 revealed that the model containing the total scores of the student engagement can predict 63 percent of the agreeableness. The $\mathrm{R}$ value is 0.25 and it indicates the correlation coefficient between teachers' selfefficacy and their personality. The square is 0.63 , and this indicates the fact that among the subscales of self-efficacy, student engagement accounts for $63 \%$ of total variance in agreeableness by itself. This correlation is significant at the 0.05 level. High student engagement skills were a good predictor of high agreeableness score.

\section{Discussion}

EFL instructors in Bandar Abbas institutes rated themselves most on conscientiousness. , and they also judged themselves to be more efficacious for instructional strategies. This is reflective of the fact that they perceived themselves as more efficacious and capable in designing instructional strategies.

The finding revealed that there is a positive and significant relationship between EFL instructors' personality and their self-efficacy, the correlation is significant at the 0.05 level. It is also concluded that there is a positive and significant relationship between Extraversion, Openness, Agreeableness, and Conscientiousness and the traits of self-efficacy; its relationship is more significant for extraversion and all components of self-efficacy and also agreeableness and two traits of self-efficacy. (Student Engagement and Instructional Strategies). The results indicate that there is a negative correlation between neuroticism and all components of teachers' self-efficacy.

According to (Somech \& Drach-Zahavy, 2000), teachers with a high level of efficacy showed extra-role behavior toward the team and the organization. Also, highly efficacious teachers show a tendency toward educational novelty and changes(Cousins \& Walker, 2000). In terms of classroom management, (Woolfolk Hoy \& Hoy, 1990) found that, high personal teacher efficacy correlated with more humanistic approaches toward pupil control and also the ability in developing positive relationships among students (Rich, Lev \& Fisher, 1996). Teacher efficacy is also related to other educational concepts such as students' learning outcomes, for example, it is found that positive personal teacher efficacy has positive effects on students' performance on language achievement tests (Tcshannen-Moran et al. 1998). Furthermore, Ross and Causin (1993) found a positive correlation between high general teaching efficacy and students' high achievement in mathematics.

All studies surveyed here are indicative of the significant contribution of teacher efficacy to positive teacher behavior and desirable student performance. All these studies indirectly highlight the need for teacher efficacy construct to be investigated in L2 teacher education due to its relation with many positive teaching/learning outcomes in the classroom.

In this study and for the purpose of finding the most considerable personality trait for teachers' self-efficacy, Agreeableness turned out to be a good predictor for student engagement and extraversion was the best predictor for instructional strategies. Furthermore, in order to identify the most considerable component of self-efficacy for personality, classroom management proved to be the best predictor for extraversion, and student engagement was the 
most important predictor of agreeableness. These findings are in line with some other studies, the findings of Rushton et al., (2007), revealed that ENFP (Extraversion, intuition, Feeling, Perceiving) types are the best teachers in the state of Florida, also in reviewing the results of another study conducted by Rothstein and Goffin (2005, p.165) on the relationship between FFM of personality and team performance, the best predictor of team related behavior was extroversion.

Navidnia (2009) explained the reason why extraversion was considered as the main predictor of teacher efficacy. He asserted that "English language classroom is by its nature a place which demands a lot of interactions, oral communications, and group work activities. In a sense, it seems that an English class is like a team and the teacher is the facilitator."

Moreover, the results of Barrick and Mount (1991) on the interface between Big Five personality dimensions and job performance criteria for five occupational groups indicated that Extroversion was the most important FFM variable for two occupations involving social interaction.

\section{References}

Akbari, R., \& Abednia, A. (2009). Second Language Teachers' Sense of Self- efficacy: A Construct Validation. TELL, Vol.3,no.11-12, 35 .

Allport, G., \& Odbert, H. (1936). Traitnames: A psycho lexical study. Psychological Monographs, 47, 211.

Bandura, A. (1977). Self-efficacy: Toward a unifying theory of behavioral change. Psychology Review, 84(2), 479507.

Bandura, A. (1986). Social foundations of thought and action: A social cognitive theory. Englewood Cliffs, NJ:

Prentice-Hall.

Barrick, M, \& Mount, M. (1991). The Big five personality dimensions and job performance: A meta-analysis.

Personnel Psychology, 44, 1-26.

Best, J. W., \& Kahn, J. V. (2006). Research in Education. Pearson Education Inc.

Bowers, M. (2006). The impact of teacher characteristics on teacher performance and students achievement: A

Judgment study of principles and superintendent. Unpublished $\mathrm{PhD}$ dissertation, University of Virginia.

Cano-Garcia, F., Padilla-Munoz, E., \& Carrasco-Ortiz, M. (2005). Personality and contextual variables in teacher

burnout, Personality and individual Differences, 38, 929-940.

Costa, P. T., \& McCrae, R. R. (1999). Inventario NEO reducido de cincofactores (NEO-FFI). Manual Professional.

Madrid. TEA Ediciones.

Emmerich, W., Roch, D., \& Trapani, C. (2006), Personality in relation to occupational outcome among established teachers, Journal of Research in Personality, 40, 501-528. Exploring the role of social trust and teaching efficacy beliefs. Teachers College Record, 108, 1155-1186.

Fisler, J. L. \& Firestone, W. A. (2006). Teacher learning in a school-university partnership:

Garousi, M. T., Mehryar, A. H., \& Ghazi Tabatabayi, M. (2001). Application of the NEO-PI_R test and analytic evaluation of its characteristics and factorial structure among Iranian University students. Journal of Humanities, 11, 173-198.

Goldberg, L. (1981). Language and individual differences: these arch for universal in personality lexicons. Beverly Hills, CA: Sage.

Homer, M. (1997). Time performance management, leadership theory: past present and future. Denton, TX: MCB University Press.

Jacquez, A. (2004). The relationship between teacher personality type and job satisfaction. Unpublished Master's thesis, Department of advanced educational studies, Morgantown University, Virginia.

John, O. (1990). The Big five factor taxonomy: dimensions of personality in the natural language questionnaires.

New York, NY: Guilford Press.

John, O. P., Donahue, E. M., \& Kentle, R. L. (1991). The Big Five Inventory-Versions 4a and 54. Berkeley, CA:

University of California, Berkeley, Institute Of Personality and Social Research. Journal of Career Assessment, 12, 395-406.

Lounsbury, J. W., Park, S. H., Sundstrom, E., Williamson, J., \& Pemberton, A. (2004).

McCombs, B, \& Miller, L. (2006). Learner-centered classroom practices and assessments: maximizing student motivation, learning and achievement. Thousand Oaks, CA: Corwin.

McCrae, R, \& Costa, P. (1990). Personality and adulthood. NewYork, NY: The Guilford Press.

Mitchell, T.R., Hopper, H., Daniels, D., George-Falvy, J.\& James, L.R. (1994).Predicting self-efficacy and performance during skill acquisition. Journal of Applied Psychology, 79, 506-517.

Navidnia, h, (2009). Technological Characteristics of English Language Teachers: On the Relationship among Big Five Personality Traits and Teacher Efficacy Beliefs. JELS, Vol.1, No. 1, Fall 2009, 79-99.

Norman, W. (1963). Toward an Adequate taxonomy of personality attributes: replicated factor structure in peer nomination personality ratings. Journal of Abnormal and Social Psychology, 66, 574-583.

Ones, D. S. Dilchert; CH. Viswesraran \& T. Judge. (2007). "In support of personality assessment in organizational settings". Personnel Psychology. 60, 995-1027. Personality, career satisfaction, and life satisfaction: Test of a directional model.

Pinker, S. (1997). How the Mind works. New York, NY: W.W. Norton \& Company.

Rich, Y., Lev, S., \& Fischer, S. (1996). Extending the concept and assessment of teacher efficacy. Educational and Psychological Measurement, 56(6), 1015-1025.

Ross, J.A., \& Cousins, J. B. (1993) .Enhancing secondary school students' acquisition of correlational reasoning skills. Research in Science \& Technological Education, 11, 191-205. 
Rothstein, M. G., \& Goffin, R. D. (2000). The assessment of personality constructs in industrial-organizational psychology. In R.D. Goffin, \& E. Helmes (Eds.), Problems and solutions in human assessment: Honoring Douglas N. Jackson at seventy (pp. 215-248). Norwell, MA: Kluwer Academic.

Rushton, J. P., C vorovic', J. \& Bons, T. A. (2007). Generalmental ability in South Asians: data from three Roma (Gypsy) communities in Serbia. Intelligence 35, 1-12.

Schmidt, C. P., B. E. Lewis, and M. J. Kurpius-Brock. (1991). Relationships between teacher personality and ratings of applied music teaching behavior. Contributions to Music Education, 18, 20-35.

Smith, R (1997). The Norton history of the human sciences. New York, NY: W.W. Norton \& Company.

Tellegan, A. (1985). Structures of mood and personality and their relevance to assessing anxiety, with an emphasis on self report. Anxiety and the anxiety disorders. Hillsdale, NJ: Erlbaum.

Tschannen-Moran, M., Woolfolk Hoy, A., \& Hoy, W. K. (1998). Teacher Efficacy: Its Meaning and Measure. Review of Educational Research, 68, 202-248.

Wood, R. E., \& Bandura, A. (1989). Impact of conceptions of ability on self-regulatory mechanisms and complex decision making. Journal of personality and social psychology, 56, 407-415.

Woolfolk, A., \& Hoy, W. K. (1990). Prospective teachers' sense of efficacy and beliefs about control. Journal of Educational Psychology, 82, 81-91.

Zhang, L. F. (2007). From career personality types to preferences for teachers' teaching styles: A new perspective on style match. Personality and Individual Differences, 43, 1863-1874. 